\title{
Plant-parasitic Nematodes Associated with Commercial Orchards of Passion Fruit and Adjacent Cerrado Vegetation in the Brazilian Federal District
}

\author{
Ana Paula Gomes de Castro ${ }^{1}$, Alexandre Moura Cintra Goulart ${ }^{2}$, Ednalva Patrícia de Andrade ${ }^{1}$, \\ Juvenil Enrique Cares ${ }^{1 *}$ and Daniel Diego Costa Carvalho ${ }^{1}$ \\ ${ }^{1}$ Departamento de Fitopatologia, Universidade de Brasília, C.P. 4457, 70910-900, Brasília, DF, Brazil \\ ${ }^{2}$ Empresa Brasileira de Pesquisa Agropecuária, Embrapa Cerrados, BR 020, Km 18, 73310-970, Planaltina, DF, Brazil \\ (Received on January 18, 2012; Revised on July 6, 2012; Accepted on July 7, 2012)
}

\begin{abstract}
Populations of plant-parasitic nematodes were evaluated in soil and root samples from areas planted with passion fruit, or covered with adjacent native cerrado vegetation, in five different cropping regions of the Brazilian Federal District. From July 2007 to January 2008, twenty samples had been collected in five Rural Centers (Núcleo Rural-NR) planted with passion fruit. In five sites, samples were also collected in native cerrado vegetation. Specimens of nine genera of plant-parasitic nematodes (Meloidogyne, Helicotylenchus, Rotylenchulus, Scutellonema, Pratylenchus, Paratylenchus, Hemicycliophora, Xiphinema and Criconemoides) were found in the present survey. Important nematode pathogens, such as Rotylenchulus reniformis and Meloidogyne spp. were observed in the passion fruit plantations throughout five major producing regions of the Brazilian Federal District.
\end{abstract}

Keywords : field survey, Meloyogyne, Passiflora spp, rootknot nematodes, Rotylenchulus reniformis

Passiflora edulis Simmonds f. flavicarpa Degener is a plant species of a high economic importance in America, whereas Brazil and Ecuador are important world producers and consumers of passion fruit (Souza et al., 2008). The economic importance of $P$. edulis and other Passiflora species relies on the quality of the fruits for consumption and on its medicinal properties (Crochemore et al., 2003). Due to favorable climatic and soil conditions, extensive production of sour passion fruit occurs in commercial orchards in the Brazilian Cerrado.

Despite the advantages mentioned above, sour passion fruit is susceptible to pests and diseases. Soil pathogens are of main concern among passion fruit growers, especially plant-parasitic nematodes. Nematodes belonging to several genera have been reported in association with Passiflora

\footnotetext{
*Corresponding author.

Phone) +82-55-061-33072191, FAX) +82-55-061-32721793

E-mail)cares@unb.br
}

root systems in Brazil (Sharma et al., 1999; Soares et al., 2003; Dias-Arieira et al., 2008), however, for the majority of them their role as pathogens remains unknown for this crop. On the other side, the root-knot nematodes (Meloidogyne javanica, M. incognita, and M. arenaria), and the reniform nematode (Rotylenchulus reniformis) are among the most destructive soil pathogens for passion fruit. These sedentary nematodes lead to root damage, poor plant development, and consequently to decreased yield and plant longevity.

In addition to preventive measures, such as planting in soil free of harmful nematodes, crop rotation is the most appropriate control measure available to lower population levels of nematodes in passion fruit plantations under Brazilian conditions. At the present time there is no nematicide registered for this crop. Despite richness of genetic variability among Passiflora germplasm, and efforts to breed nematode resistant varieties (Castro et al., 2011; ElMoor et al., 2009; Sharma et al., 2002), commercial varieties are not yet available to growers. Thus, knowledge of the distribution and population levels of nematodes is required for implementation of management practices.

Direct field seeding, instead of planting seedlings from nurseries is a common practice among passion fruit growers in the Brazilian Federal District (DF). This practice contributes to avoid dissemination of nematodes and other pathogens from the nurseries through planting materials. Under these conditions, the sources of soil contamination of plant-parasitic nematodes in the commercial orchards are possibly from previous crops, weeds, or accidental introduction of infested soil from other locations. Susceptible plants from the native vegetation may also be the source of plant-parasitic nematodes when the area is claimed for agricultural purposes. For instance, Souza et al. (1994) reported the association of Meloidogyne spp. with several native plants of cerrado vegetation in Brazilian Federal District (DF). The fact that the same plant-parasitic nematodes appear associated with crops and plants in the associated native vegetation is an indication that these 
nematodes had been there before the area was cleared for planting. Therefore, the objective of this work was to verify the occurrence and distribution of plant-parasitic nematodes in passion fruit orchards and the adjacent native cerrado areas in DF.

\section{Sampling in passion fruit orchards and native cer- rado areas}

Samples containing roots and rhizosphere soil were collected in passion fruit commercial orchards in the main growing areas throughout the Brazilian Federal District (DF), from May 2007 to January 2008 (Fig. 1). Samples were obtained from orchards in their productive phase. About $22 \%$ of DF passion fruit growers, chosen at random were included in this study. Twenty composite samples were collected in the rhizosphere of passion fruit. Samples 1, 2 and 3 from Nucleo Rural Lago Oeste (15³4'38"S; 47 59'59"W; $1301 \mathrm{~m})$ 4, 5, 6, 7, 8 and 9 from NR Pipiripau (15³0'55"S; 47²9'34"W; $1097 \mathrm{~m})$; 10, 11, 12 and 13 from NR Gama (1557'41"S; 4804'75"W; $1269 \mathrm{~m}) ; 14,15$ and 16 from NR Brazlândia $\left(15^{\circ} 38^{\prime} 05^{\prime \prime} \mathrm{S} ; 48^{\circ} 06^{\prime} 85^{\prime \prime} \mathrm{W}\right.$; $1133 \mathrm{~m})$; and 17, 18, 19 and 20 from NR Paranoá (1554'16.71"S; 47²2'28.55"W; $854 \mathrm{~m})$. Five samples were collected in adjacent native cerrado areas (one sample from each NR), from a total of 13 properties (Fig. 1). Each composite sample was made up of 10 subsamples ha ${ }^{-1}$ of soil and roots obtained from the depth of $0-20 \mathrm{~cm}$. One liter of soil and $100 \mathrm{~g}$ of roots were saved for analysis. Only soil was collected in native cerrado.

\section{Extraction and identification of nematodes}

The methods reported by Jenkins (1964) and Coolen and
D'herde (1972) were used to extract nematodes from soil and roots, respectively. The nematodes were extracted from $200 \mathrm{cc}$ of soil. The soil was suspended in about 5 liters of water in a bucket. After homogenization and resting for about 1 min., the suspension was poured through a 45 mesh sieve, and the nematodes collected in a 500 mesh sieve. The suspension collected in the last sieve was equally distributed in centrifuge flasks, then to each flask was added $1 \mathrm{cc}$ of kaolin. After centrifugation at $1800 \mathrm{rpm}$ for $5 \mathrm{~min}$., the supernatant was removed, and sucrose solution (45\%) was added to each tube for a second round centrifugation at $1800 \mathrm{rpm}$ for $1 \mathrm{~min}$. The supernatant was collected in a 500 mesh sieve and washed with running water, and finally, clean nematode suspension was collected in a beaker. Root nematodes were extracted from $10 \mathrm{~g}$ of roots chopped into pieces of about $1 \mathrm{~cm}$ and blended in water for $15 \mathrm{sec}$. Plant tissues were removed in a 20 mesh sieve and the nematodes collected in a 500 mesh sieve. The nematode suspension was cleared by centrifugation in sucrose solution following the same procedures described above. Extracted nematodes were suspended in water, killed by gradual heating, and fixed in a $3 \%$ formaldehyde solution. The number of nematodes extracted from each sample was estimated in a Peters chamber, under a light microscope (Zeiss Axiovert $135 \mathrm{M}$ ), using $30 \%$ of total volume of each soil suspension. The nematodes were glycerin infiltrated (Seinhorst, 1959; Cares and Huang, 2008), transferred to permanent slide mounts and examined under a light microscope. Taxonomic identification was made up to the genus level.

\section{Sampling design and statistical analysis}

Data on plant-parasitic nematodes were obtained in triplicate for each composite sample. The 20 composite samples

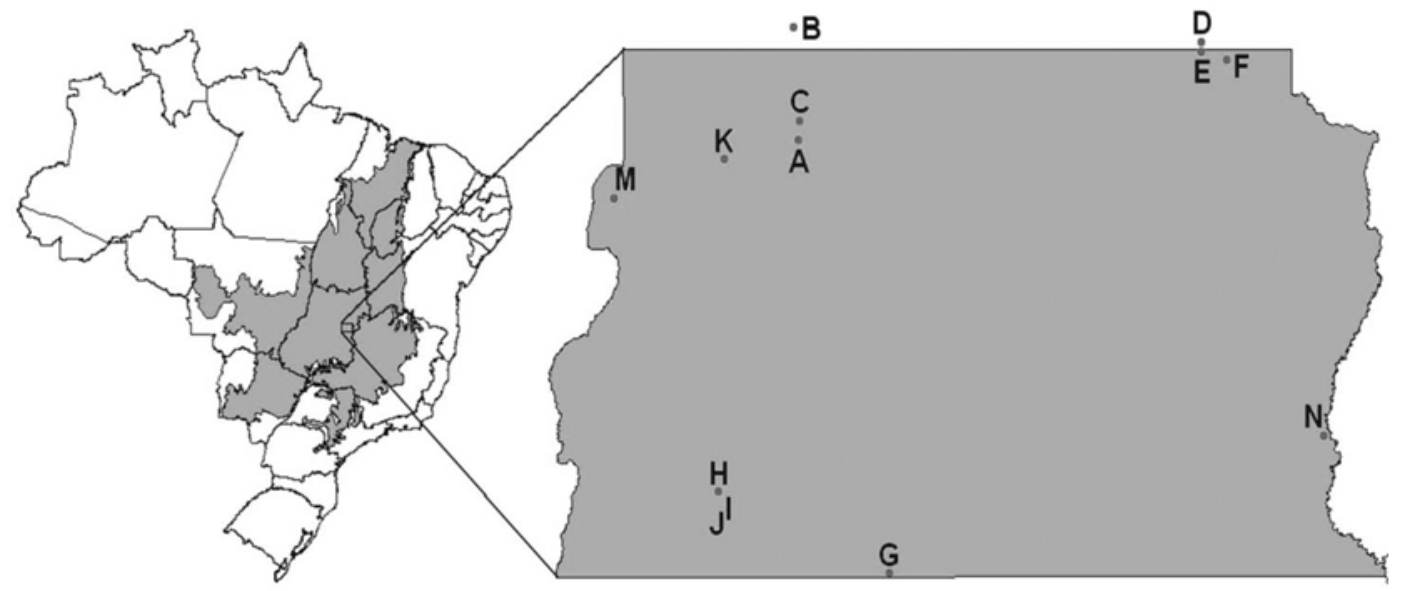

Fig. 1. Sampling sites of roots and rhizosphere soil collected in commercial passion fruit orchards and adjacent native cerrado areas in the Brazilian Federal District. A, B, C) Núcleo Rural Lago Oeste (A = area 1; B = area 2; C = area 3); D, E, F) NR Pipiripau (D=area 4; E = area 5; $\mathrm{F}=$ areas 6, 7, 8 and 9); G, H, I, J) NR Gama $(\mathrm{G}=$ area $10, \mathrm{H}=$ area $11, \mathrm{I}=$ area $12 ; \mathrm{J}=$ area 13$) ; \mathrm{K}, \mathrm{M}) \mathrm{NR}$ Brazlândia $(\mathrm{K}=$ areas 14 and $15 ; \mathrm{M}=$ area 16); N) NR Paranoá ( $\mathrm{N}=$ areas 17, 18, 19 and 20). Shaded areas on map of Brazil represent cerrado as the main vegetation. 
included: three samples from NR Lago Oeste (nine replicates altogether); six from NR Pipiripau (18 replicates altogether); four from NR Gama (12 replicates altogether); three from NR Brazlândia (nine replicates altogether) and four from NR Paranoá (12 replicates altogether). In Table 2, means obtained for each rural center (three per NR) were analyzed separately for the number of specimens per sample of Meloidogyne spp. and Rotylenchulus reniformis. For soil from natural cerrado vegetation, the means correspond to five samples (one sample per NR), comprising three replicates per sample. In Table 1, means obtained for each nematode genus correspond to 20 composite samples analyzed together. For every one of the 3 replicates, total number of nematodes found in each NR was added as follows: replicate $\mathbf{1}=$ mean of replicate $1(\mathrm{mr} 1)$ for $\mathrm{NR}$ Lago Oeste + mr1 NR Pipiripau + mrl NR Gama + mr1 NR Brazlândia + mr1 NR Paranoá; replicate $2=m r 2$ for NR Lago Oeste + mr2 NR Pipiripau + mr2 NR Gama + $\mathrm{mr} 2$ NR Brazlândia $+\mathrm{mr} 2 \mathrm{NR}$ Paranoá; replicate $3=\mathrm{mr} 3$ for NR Lago Oeste + mr3 NR Pipiripau + mr3 NR Gama + mr3 NR Brazlândia + mr3 NR Paranoá. For soil from natural cerrado vegetation, the means correspond to 5 samples (1 sample per NR), being 3 replicates per sample as follow: replicate $\mathbf{1}=$ replicate 1 (rep. 1) for NR Lago Oeste + rep. 1 NR Pipiripau + rep. 1 NR Gama + rep. 1 NR Brazlândia + rep. 1 NR Paranoá; replicate $\mathbf{2}=$ rep. 2 for NR Lago Oeste + rep. 2 NR Pipiripau + rep. 2 NR Gama + rep. 2 NR Brazlândia + rep. 2 NR Paranoá; replicate $3=$ rep. 3 for NR Lago Oeste + rep. 3 NR Pipiripau + rep. 3 NR Gama + rep. 3 NR Brazlândia + rep. 3 NR Paranoá. Means were submitted to analysis of variance, and compared by the Scott-Knott test at 5\% probability, using SISVAR software (Ferreira, 2008).

In this survey, specimens belonging to nine genera of plant-parasitic nematodes were recovered (Criconemoides Taylor, 1936; Helicotylenchus Steiner, 1945; Hemicycliophora De Man, 1921; Meloidogyne Goeldi, 1887; Paratylenchus Micoletzky, 1925; Pratylenchus Filipjev, 1936; Rotylenchulus Linford and Oliveira, 1940; Scutellonema Andrassy, 1958 and Xiphinema Cobb, 1913) (Table 1). Meloidogyne spp. and Rotylenchulus reniformis were the most common species in passion fruit plantations (Table 1). Helicotylenchus spp. and Criconemoides spp. occurred in lower populations in the orchards. Pratylenchus spp., Scutellonema spp., Hemicycliophora spp. and Paratylenchus spp. were detected in insignificant levels in the orchards. Xiphinema spp., were limited to cerrado areas, while Scutellonema spp. and Paratylenchus spp. were not detected in cerrado soils.

Total number of Meloidogyne spp. and $R$. reniformis per sample was higher in passion fruit orchards than in native cerrado (Table 1). Important plant-parasitic nematodes such as Meloidogyne spp. were generally more abundant in agricultural soils as compared with neighboring native areas. Several factors can contribute to determine nematode abundance in soil under different conditions, but certainly host suitability plays an important role in nematode density. For example, Mattos (1999) compared nematode communities in association with four different plant community types of native cerrado vegetation, with adjacent cropping fields planted with perennial (eucalyptus and coffee) and

Table 1. Plant-parasitic nematodes extracted from samples collected in passion fruit orchards and adjacent native cerrado vegetation, in the Brazilian Federal District (July 2007-January 2008)

\begin{tabular}{|c|c|c|c|}
\hline \multirow{3}{*}{ Nematodes } & \multicolumn{3}{|c|}{ "Sampling conditions ${ }^{\mathrm{d}}$} \\
\hline & \multicolumn{2}{|c|}{ Passion fruit plantations $\mathrm{s}^{\mathrm{b}}$} & \multirow{2}{*}{$\frac{\text { Native cerrado }^{c}}{\text { Nematode No./200 cc of soi }}$} \\
\hline & Nematode No./10 g roots & Nematode No./200 cc of soil & \\
\hline Meloidogyne spp. & $7.6 \mathrm{~b}$ & $26.4 b^{a}$ & $20.0 \mathrm{bA}$ \\
\hline Rotylenchulus reniformis & $12.8 \mathrm{a}$ & $71.2 \mathrm{aB}$ & $4.6 \mathrm{dA}$ \\
\hline Helicotylenchus spp. & $6.9 \mathrm{c}$ & $8.7 \mathrm{cA}$ & $40.3 \mathrm{aB}$ \\
\hline Criconemoides spp. & $0.9 \mathrm{~d}$ & $6.2 \mathrm{cA}$ & $14.0 \mathrm{cB}$ \\
\hline Pratylenchus spp. & $0.3 \mathrm{e}$ & $0.2 \mathrm{dA}$ & $1.6 \mathrm{eA}$ \\
\hline Scutellonema spp. & $0.6 \mathrm{~d}$ & $0.6 \mathrm{dA}$ & 0 fA \\
\hline Paratylenchus spp. & $0 \mathrm{e}$ & $0.3 \mathrm{dA}$ & 0 fA \\
\hline Xiphinema spp. & $0 \mathrm{e}$ & $0 \mathrm{dA}$ & $0.3 \mathrm{fA}$ \\
\hline Hemicycliophora spp. & $0.3 \mathrm{e}$ & $0 \mathrm{dA}$ & $0.3 \mathrm{fA}$ \\
\hline $\mathrm{CV}$ & $7.92 \%$ & $13.39 \%$ & $8.24 \%$ \\
\hline
\end{tabular}

${ }^{a}$ Means followed by the same letter, lowercase in the columns and uppercase in the rows, do not differ by the Scott-Knott test at $5 \%$ probability.

${ }^{\mathrm{b}}$ Means corresponding to 20 composite samples ( 3 samples for NR Lago Oeste; 6 for NR Pipiripau; 4 for NR Gama; 3 for NR Brazlândia and 4 for NR Paranoá).

${ }^{\mathrm{c}}$ Means corresponding to 5 samples ( 1 sample for each NR).

${ }^{\mathrm{d}}$ Replicates 1,2 and 3 of each NR were separately added to comprise the 3 replicates used in the analysis. 
Table 2. Abundance (number of nematodes per $200 \mathrm{cc}$ of soil) of Meloidogyne spp. and Rotylenchulus reniformis in commercial passion fruit orchards and adjacent native cerrado areas in the Brazilian Federal District (July 2007-January 2008)

\begin{tabular}{|c|c|c|c|c|}
\hline \multirow{2}{*}{ Sites (Rural Center) } & \multicolumn{2}{|c|}{ Meloidogyne spp. } & \multicolumn{2}{|c|}{ R. reniformis } \\
\hline & Passion fruit & Native cerrado & Passion fruit & Native cerrado \\
\hline Lago Oeste & $2.4 \mathrm{cB}^{\mathrm{a}}$ & $0 \mathrm{dA}$ & $1.4 \mathrm{cA}$ & $0 \quad \mathrm{cA}$ \\
\hline Pipiripau & $1.4 \mathrm{~dB}$ & $0 \mathrm{dA}$ & $26.7 \mathrm{aB}$ & $0 \quad \mathrm{cA}$ \\
\hline Gama & $13.8 \mathrm{aA}$ & $12.6 \mathrm{aB}$ & $12.0 \mathrm{bB}$ & $1.3 \mathrm{bA}$ \\
\hline Brazlândia & $8.0 \mathrm{bB}$ & $1.6 \mathrm{cA}$ & $31.0 \mathrm{aB}$ & $3.0 \mathrm{aA}$ \\
\hline Paranoá & $0.7 \mathrm{eA}$ & $5.6 \mathrm{bB}$ & $0 \mathrm{dA}$ & $0.3 \mathrm{cA}$ \\
\hline $\mathrm{CV}$ & $5.93 \%$ & $19.76 \%$ & $18.08 \%$ & $26.35 \%$ \\
\hline
\end{tabular}

${ }^{a}$ Means followed by the same letter, lowercase in the columns and uppercase in the rows, do not differ by the Scott-Knott test at $5 \%$ probability.

annual (maize and tomato) plants. In areas of native vegetation, an average of 13 to 31 juveniles (J2) of Meloidogyne spp. were recovered in $500 \mathrm{cc}$ of soil, while 24 were recovered in the same volume in eucalyptus and 688 in tomato crops, with intermediate values for coffee and maize samples.

High populational levels of the root-knot nematode, and of the reniform nematode were observed. Higher abundance values of Meloidogyne spp. occurred in NR Gama and NR Brazlândia, while highest frequencies for $R$. reniformis were detected in NR Pipiripau, NR Gama and NR Brazlândia (Table 2). High levels of Meloidogyne spp. present in adjacent areas of cerrado in NR Gama suggest these areas of native vegetation as possible sources of inoculum of the root-knot nematode to the passion fruit plantations, as postulated by Souza et al. (1994). This possibility was also verified in NR Brazlândia and NR Paranoá. Lower levels of Meloidogyne spp. in samples from passion fruit soils in NR Lago Oeste and NR Pipiripau was in accordance with absence of this nematode in samples of adjacent native vegetation.

Higher levels of $R$. reniformis in orchards of NR Gama and NR Brazlândia, and the presence of the nematode associated with local native vegetation support the hypothesis of preexisting populations of the nematode in previous native cerrado. Conversely, high levels of $R$. reniformis found in NR Pipiripau combined with absence of the nematode in adjacent cerrado, and its geographic isolation suggest that these orchards were contaminated with nematode-infected seedlings or inoculum coming from other sources.

Attempts have been made to determine the occurrence and distribution of harmful nematodes associated with passion fruit orchards in the Brazilian Federal District (DF). In a preliminary survey in DF and in the neighboring states of Goiás and Minas Gerais, Sharma et al. (1999) verified the occurrence of $M$. javanica, $M$. incognita, M. arenaria,
R. reniformis, Pratylenchus brachyurus, Helicotylenchus dihystera and Criconemella ornata. In addition, Sharma et al. (2002) associated the symptoms of plant stunting, leaf yellowing and plant death, with root galls caused by the root-knot nematode in DF.

Our study suggests a generalized distribution of the rootknot and the reniform nematodes through commercial passion fruit orchards, since Meloidogyne spp. and $R$. reniformis were found, respectively, in all and in four of five, of the five major producing regions throughout DF, from north to south, east to west (Table 2, Figure 1). Except for Scutellonema spp. and Paratylenchus spp., all other nematodes found in commercial orchards were also present in areas of native vegetation, suggesting previous occurrence of those nematodes associated with local native plants, before human intervention with the introduction of agricultural crops. Xiphinema spp. were recovered only in samples collected in native areas. It suggests that this nematode is more sensitive to environmental disturbances, such as agricultural cultivation. Another hypothesis could rely on the possibility of the planted passion fruit varieties not being hosts of this nematode.

The root-knot nematode (M. incognita, M. arenaria and M. javanica) and the reniform nematode have become economically important in passion fruit plantations (Ritzinger et al., 2001; Robinson et al., 1997). The root-knot nematode was also associated with passion fruit decline in other Brazilian states such as Bahia, Ceará, Maranhão, Pernambuco, Piauí, Rio Grande do Norte and Sergipe, while R. reniformis was reported only in Pernanbuco State (Ponte, 1992). Some nematode surveys had been carried out in other countries aiming to alert growers, and to give directions for control practices (Bridge et al., 1996; Knight, 2001). Thus, our results show presence of economically important nematodes in major passion fruit plantations in the Brazilian Federal District, as an indication for implementing crop rotation and other available measures to control nematodes. 


\section{Acknowledgments}

This work was supported by Coordenação de Aperfeiçoamento de Pessoal de Nível Superior (CAPES), Conselho Nacional de Desenvolvimento Científico e Tecnológico (CNPq) and Embrapa Cerrados. The authors acknowledge Dr. Loiselene C. Trindade (Emater-DF) for providing means of contact with passion fruit growers. They also acknowledge Fábio G. Faleiro and Nilton T. V. Junqueira for general support and Emanuelita Cavalcante (Embrapa Cerrados) for her kind support during laboratory work.

\section{References}

Bridge, J., Hunt, D. J. and Hunt, P. 1996. Plant-parasitic nematodes of crops in Belize. Nematropica 26:111-119.

Cares, J. E. and Huang, S. P. 2008. Soil nematodes. In: $A$ handbook of tropical soil biology, ed. by Moreira, F. M. S., Huising, E. J. and Bignell, D. E. pp. 97-106. Earthscan, London.

Castro, A. P. G., Faleiro, F. G., Carvalho, D. D. C., Fonseca, K. G., Vilela, M. F., Junqueira, N. T. V. and Cares, J. E. 2011. Genetic variability of Passiflora spp. from commercial fields in the Federal District, Brazil. Ciência Rural 41:996-1002.

Coolen, W. A. and D'herde, C. J. 1972. A method for the quantitative extraction of nematodes from plant tissue. State Nematology and Entomology Research Station, Ghent.

Crochemore, M.L., Molinari, H. B. C. and Vieira, L. G. E. 2003. Genetic diversity in passion fruit (Passiflora spp.) evaluated by RAPD markers. Braz. Arch. Biol. Techn. 46:521-527.

Dias-Arieira, C. R., Molina, R. O. and Costa, A. T. 2008. Nematoides Causadores de Doenças em Frutíferas. Agroambiente On-line 2:46-56.

El-Moor, R. D., Peixoto, J. R., Ramos, M. L. G. and Mattos, J. K. A. 2009. Reação de genótipos de maracujazeiro-azedo aos nematoides de galhas (Meloidogyne incognita e Meloidogyne javanica). Biosci. J. 25:53-59.
Ferreira, D. F. 2008. SISVAR: um programa para análises e ensino de estatística. Rev. Cient Symposium 6:36-41.

Jenkins, W. R. 1964. A rapid centrifugal flotation technique for separating nematodes from soil. Plant Dis. Rep. 48:62.

Knight, K. W. L. 2001. Plant parasitic nematodes associated with six subtropical crops in New Zealand. New Zeal. J. Crop. Hort. 29:267-275.

Mattos, J. K. A. 1999. Caracterização das comunidades de nematoides em oito sistemas de uso da terra nos cerrados do Brasil central. Ph.D. Thesis, University of Brasilia, Brasília, Brazil.

Ponte, J. J. 1992. The yellow passion fruit plant nematoses in the northeast of Brasil. Nematologia Brasileira 16:77-79.

Ritzinger, C. H. S. P., Sharma, R. D. and Junqueira, N. T. V. 2001. Nematoides. In: Aspectos fitossanitários do maracujá amarelo e maracujá doce, ed. by Santos Filho, H. P. Embrapa Comunicação para Transferência de Tecnologia, Brasília, DF, Brazil.

Robinson, A. F., Inserra, R. N., Caswell-Chen, E. P., Vovlas, N. and Trocolli, A. 1997. Rotylenchulus Species: Identification, distribution, host ranges, and crop plant resistance. Nematropica 27:127-180.

Sharma, R. D., Junqueira, N. T. V. and Gomes, A. C. 1999. Nematoides nocivos ao maracujazeiro. Comunicado Técnico, 4. Embrapa Cerrados, Planaltina, DF, Brazil .

Sharma, R. D., Junqueira, N. T. V. and Gomes, A. C. 2002. Reaction of passion fruit varieties to the root-knot nematode, Meloidogyne javanica. Nematologia Brasileira 26:93-96.

Soares, P. L. M., Santos, J. M. and Lehman, P. S. 2003. Estudo morfométrico comparativo de populações de Rotylenchulus reniformis (Nemata: Rotylenchulinae) do Brasil. Fitopatologia Brasileira 28:292-297.

Souza, M. M., Pereira, T. N. S. and Vieira, M. L. C. 2008. Cytogenetic studies in some species of Passiflora L. (Passifloraceae): A review emphasizing Brazilian species. Braz. Arch. Biol. Techn. 51:247-258.

Souza, R. M., Dolinski, C. M. and Huang, S. P. 1994. Survey of Meloidogyne spp. in native cerrado of Distrito Federal, Brazil. Fitopatologia Brasileira 19:463-465. 